\title{
The Effect of Ethanolic Extract of Myrmecodia pendans on Gentamicin Induced Nephrotoxicity in Wistar Rats
}

\author{
I Made Merdana ${ }^{1,4 *}$, Ni Luh Watiniasih ${ }^{2}$, I Wayan Sudira ${ }^{3}$, Anak Agung Gde Arjana ${ }^{3}$, I Wayan Nico \\ Fajar Gunawan ${ }^{4}$, Luh Made Sudimartini ${ }^{4}$ and Ketut Budiasa ${ }^{3}$ \\ ${ }^{1}$ Laboratory of Veterinary Pharmacy and Pharmacology, Faculty of Veterinary Medicine, Udayana University, Indonesia \\ ${ }^{2}$ Department of Biology, Faculty of Mathematic and Natural Science, Udayana University, Indonesia \\ ${ }^{3}$ Department of Veterinary Basic Science, Faculty of Veterinary Medicine, Udayana University, Indonesia \\ ${ }^{4}$ Department of Veterinary Clinic, Faculty of Veterinary Medicine, Udayana University, Indonesia \\ *Corresponding author: imade_merdana@unud.ac.id
}

Article History: $20-132 \quad$ Received: 06-Jun- $20 \quad$ Revised: $22-\mathrm{Nov}-20 \quad$ Accepted: $25-\mathrm{Nov}-20$
ABSTRA C T
The purpose of the study was to investigate the nephroprotective effect of the Myrmecodia pendans extract on Wistar
rats. The nephrotoxicity of the animals was induced through intra-peritoneal administration of $100 \mathrm{mg} / \mathrm{kg} / \mathrm{day}$ of
gentamicin for ten days. The effect of $M$. pendans extract at a dose of $250 \mathrm{mg} / \mathrm{kg} / \mathrm{day}$ was concurrently monitored in
some rats by assessing their serum creatinine levels, blood urea nitrogen $(\mathrm{BUN})$ and the histopathological parameters.
The mean of serum creatinine in control group was $1.17 \pm 0.18 \mathrm{mg} / \mathrm{dl}$ and in nephrotoxic group it was $2.22 \pm 0.29 \mathrm{mg} / \mathrm{dl}$,
while in group given the extract were $1.38 \pm 0.19$ and $1.27 \pm 0.15 \mathrm{mg} / \mathrm{dl}$, respectively. In that group also sequentially
showed BUN levels of $24.27 \pm 2.6,108.13 \pm 11.58,30.70 \pm 4.23$ and $27.28 \pm 2.84 \mathrm{mg} / \mathrm{dl}$, respectively. Nephrotoxicity was
induced in the animals injected with gentamicin, which showed a significant $(\mathrm{P}<0.05)$ increase in creatinine and BUN
compared with control group. The results also showed that the $M$. pendans ethanolic extracts significantly (P<0.05)
prevented the increase in the levels of serum creatinine, BUN and reduced renal histopathological damage such as
hydropic degeneration, vascular congestion and tubular necrosis. Therefore, the ethanolic extract of $M$. pendans exhibits
a nephroprotective activity.

Key words: BUN; Creatinine; Myrmecodia pendans; Nephroprotective.

C2020 IJVS - All Rights Reserved

\section{INTRODUCTION}

Myrmecodia pendans is a native herbal plant from Papua, Indonesia, used to treat various diseases (Javaid et al. 2012). It is a unique plant due to the interaction between its stem tubers and ants, which produce chemical compounds such as flavonoids, titerphenoid, tannin, tocopherols, phenol, and are also rich in minerals (Sudiono et al. 2015). Also, it contains five types of flavonoids, namely: kaempferol, lutelin, routine, quercetin, and apigenin (Engida et al. 2015). These active compounds are antioxidant (Wimpy, 2014), anticancerous (Soeksmanto et al. 2010; Yap et al. 2017), antibacterial (Gartika et al. 2018), anti-inflammatory (Islamoyo et al. 2018), immunomodulatory (Hertiani et al. 2010), hepato-protector (Merdana et al. 2019) in nature and also accelerate healing processes (Epsilawati et al. 2019). Therefore, there is important to explore the properties of these antioxidant compounds in eradicating free radicals' scavengers (Khalid et al. 2011). Previous studies showed that its extract exhibited the ability as hepato-protector at a dose of 250 $\mathrm{mg} / \mathrm{kg} /$ day in rats (Merdana et al. 2019).

It has been reported that free radicals are the main mediators of physiological organ abnormalities, and one such is kidney problems. Kidneys, as part of the body's vital organs, play a major role in blood filtration and eliminating waste products derived from endogenous and xenobiotic metabolism. Other functions include regulating the body's fluid and electrolyte balance, homeostatic system, and secretion of substances needed by the body such as renin, cholecalciferol, erythropoietin, and prostaglandin. Impaired kidney function could be as a result of infections, tumors, congenital abnormalities, and metabolic or degenerative diseases. These disorders could develop into chronic kidney disease if not well-managed, usually arising slowly and becoming chronic (Acharya et

Cite This Article as: Merdana IM, Watiniasih NL, Sudira IW, Arjana AAG, Gunawan IWNF, Sudimartini LM, and Budiasa K, 2021. The effect of ethanolic extract of Myrmecodia pendans on gentamicin induced nephrotoxicity in Wistar Rats. International Journal of Veterinary Science 10(2): 96-101. https://doi.org/10.47278/journal.ijvs/2020.025 
al. 2013; Barnett and Cummings, 2018). Most of these diseases are mediated by the presence of free radicals, which cause damage to kidney cells. In addition, numerous studies have shown that aminoglycosides, such as gentamicin, develop oxidative stress in the renal cortex, therefore, are often used in inducing nephrotoxic state in animal models (Ali et al. 2011; Lee et al. 2012).

Gentamicin-induced nephrotoxicity involves several mechanisms, classified as vascular, glomerular, and tubular. These different toxico-pathological effects occurred due to induction of gentamicin with different doses and pathways. Gentamicin causes tubular damage through necrosis of proximal tubular epithelial cells and changes in cellular endocytosis function (Saleemi et al. 2009; Javed et al. 2013). Gentamicin causes mesongial contractions and reduces glomerular filtration in the glomerulus, which is the first part of nephron in contact with it. Additionally, its administration leads to a decrease in renal blood flow due to an increase in vascular resistance, but without reducing perfusion pressure. This decrease in blood flow causes a reduction in glomeruli filtration, and the oxygen supply of ATP at the tubules (Randjelovic et al. 2017). The increased accumulation of gentamicin in proximal tubules is due to the expression of protein molecule transport and cations in these regions (Quiros et al. 2011). Also, the megalin-cubilin complex has been reported for being responsible for gentamicin transport by endocytosis (Nolin and Himmelfarb, 2010). This causes injury to the kidney through oxidative stress. Saleemi et al. (2009) reported the toxico-pathological effect of intramuscular administration of gentamicin in a day-old chick resulted in kidneys enlarged, hemorrhagic and tubular necrosis. Kidney function tests could be identified by measuring serum creatinine and blood urea nitrogen levels and histopathological examination (Alarifi et al. 2012; Salgueiro et al. 2015). Therefore, this study aims to determine the nephroprotective effect of ethanolic extract of $M$. pendans on gentamicin-induced nephrotoxic rats.

\section{MATERIALS AND METHODS}

\section{Ethical Approval}

The research has been approved by the Ethical Commission for the Use of Animals in Research and Education of the Faculty of Veterinary Medicine, Udayana University, with the approval letter number 1780a/UN14.2.9/PD/2019.

\section{Preparation of $M$. pendans Extract}

The extraction process was conducted at the Biopetisida Laboratory of Udayana University. An air-dried sample of $M$. pendans originated from Papua, Indonesia, was ground into powder. Then macerated in $90 \%$ ethanol with a ratio of 1:3 (w/v), mixed in a shaker for about 2-3 hours, and then stored for 72 hours. The resultant sample was filtered using filter papers, and the supernatant was evaporated in a rotary evaporator. The extract was stored in the refrigerator before it was used (Zhang et al. 2018).

\section{Preparation of the Experimental Animals}

The research was conducted at the Veterinary Pharmacy and Pharmacology Laboratory of Udayana
University. A total number of 24 healthy male Wistar rats, aged 3-4 months old, and weighing 200-250 grams were used for the study. These animals were allowed to acclimatize to laboratory conditions for fifteen days in a cage before being treated. During the period, the rats continuously had free access to good feeds and drinking water. Also, all the experimental procedures were done at the same laboratory conditions to minimize handling stress.

\section{Treatments of the Animals}

The nephrotoxicity of the animals was induced through intra-peritoneal administration of gentamicin (PT. Bernofarm) at a dose of $100 \mathrm{mg} / \mathrm{kg} /$ day IP for ten days. The effect of $M$. pendans extract at a dose of $250 \mathrm{mg} / \mathrm{kg} / \mathrm{day}$ administered orally was concurrent on the rats. Then, the levels of creatinine serum and BUN in these nephrotoxic rats were assessed, and the histopathological examination gave the parameters of renal damage. Also, the animals were randomly divided into four groups; I, II, III, and IV. Group I was the control group that received normal saline solutions (Na-CMC, Bratacoß) IP for ten days. Group II received gentamicin at a dose of $100 \mathrm{mg} / \mathrm{kg} / \mathrm{day}$. Group III received gentamicin at a dose of $100 \mathrm{mg} / \mathrm{kg} / \mathrm{day}$ and $M$. pendans extract at a dose of $250 \mathrm{mg} / \mathrm{kg} /$ day. Group IV received $M$. pendans extract at a dose of $250 \mathrm{mg} / \mathrm{kg} / \mathrm{day}$ for seven days and continued with $100 \mathrm{mg} / \mathrm{kg} /$ day gentamicin, and $M$. pendans extract at a dose of $250 \mathrm{mg} / \mathrm{kg} /$ day for the remaining days. Then, all the animals were weighed on the eleventh day and the blood sample of each animal was collected through cardiac puncture under diethyl ether anesthesia. Finally, the kidneys of the animals were removed, weighed and then histopathologically studied.

\section{Measurement of Serum Creatinine and Blood Urea Nitrogen (BUN) Levels}

The blood samples were processed in a standard clinic automatic instrument (Semi-auto Chemistry AnalyzerIchem-535Vet, Icubio) to obtain the serum creatinine and BUN levels. The chemical reagent used for the serum creatinine test was Creatinine ST Reagensia (PT. Gresik Sarana Tirta), while Mocznik/Urea kit (BioMaxima, Poland) was used for the BUN test. The results of both tests were expressed in milligrams per deciliter $(\mathrm{mg} / \mathrm{dl})$.

\section{Histopathological Examination}

The animals were necropsied following the procedure, and the kidneys were stored in $10 \%$ neutral bufferd formalin. These were sliced, stained with hematoxylin and eosin (Feldman and Wolfe 2014), and then examined under a light microscope (Geller and Horowitz 2014). Assessment of the histopathological changes was done through scoring; Score 0: Normal. Score 1: Granulovascular debris in tubular lumens with or without evidence of cell desquamation of small foci $(<1 \%$ of the total tubular population). Score 2: Tubular epithelial necrosis and easily seen desquamation but involving less than half of cortical tubules. Score 3: More than half tubules showing desquamation necrosis, which are easily seen. Score 4: Complete or almost complete tubular necrotized (Kapić et al. 2014).

\section{Statistical Analysis}

The quantitative data were presented as mean \pm SD Then, the parametric data such as serum creatinine, BUN, 
Int J Vet Sci, 2021, 10(2): 96-101.

renal weight and renal index were subjected to One-way Analysis of Variance and followed by Duncan test. The histopathological scores were subjected to non-parametric Kruskall Wallis followed by Mann-Whitney test and variations between animal groups of $\mathrm{P}<0.05$ were considered statistically significant.

\section{RESULTS}

\section{Weight and Renal Index of Experimental Animals}

The renal index was determined by comparing renal weight to the bodyweight of the rat. Based on the results, the renal weight of nephrotoxic animals increased, as well as the renal index. Also, there was a significant increase $(\mathrm{P}<0.05)$ in both the mean weight and renal index of the group of animals induced with gentamicin compared with the control and the groups that received $M$. pendans extract, as shown in Fig. 1.

\section{Effect of $M$. pendans Extract on the Blood}

The mean of serum creatinine in group I, the control, was $1.17 \pm 0.18 \mathrm{mg} / \mathrm{dl}$. Administration of gentamicin in group II successfully induced nephrotoxicity in rats, shown by an increase in serum creatinine level at $2.22 \pm 0.29 \mathrm{mg} / \mathrm{dl}$. While the mean of serum creatinine of animals in groups III and IV were $1.38 \pm 0.19$ and $1.27 \pm 0.15 \mathrm{mg} / \mathrm{dl}$, respectively. Based on statistical analysis, the administration of gentamicin in group II significantly $(\mathrm{P}<0.05)$ increased the serum creatinine compared with the control group. However, the administration of $M$. pendans extracts in groups III and IV significantly $(\mathrm{P}<0.05)$ reduced the serum creatinine levels when compared with group II, but showed no significant differences $(\mathrm{P}<0.05)$ with the control group, as shown in Fig. 2.

The mean BUN in the control group was $24.27 \pm 2.69 \mathrm{mg} / \mathrm{dl}$. This value is within the range of normal BUN, which is $8-25 \mathrm{mg} / \mathrm{dl}$. Also, there was a high increase in BUN in group II, at $108.13 \pm 11.58 \mathrm{mg} / \mathrm{dl}$. In groups III and IV, the BUN was $30.70 \pm 4.23$ and $27.28 \pm 2.84 \mathrm{mg} / \mathrm{dl}$, respectively. However, its levels in control and treated groups with $M$. pendans extract showed significant differences $(\mathrm{P}<0.05)$ compared with the nephrotoxic group, as shown in Fig. 3.

\section{Histopathological Evaluation}

Based on the histopathological examination, the control group showed normal glomerular and tubular histology (Fig 4). Gentamicin-induced nephrotoxicity in rats could be discovered through histological changes in the form of epithelial desquamation and degeneration of more than half of the proximal tubules. Renal histopathological changes included tubular congestion lesions with nephrosis, tubular necrosis, epithelial desquamation, hydropic degeneration, lipidosis, interstitial edema, and vascular congestion (Fig. 5). The administration of $M$. pendans extracts for therapeutic and prophylactic purposes in group III and IV animals showed improvement of the tubular histological structure by significantly $(\mathrm{P}<0.05)$ decreasing scores of the histopathological damage on groups induced with gentamicin (Fig. 6 and Fig. 7). The results are shown in Table 1.
Table 1: Effect of $M$. pendans extract on the nephrotoxic-rats Groups Histopathological Parameters Histological $(\mathrm{n}=24) \quad$ Score

\begin{tabular}{|c|c|c|c|c|}
\hline & & & & \\
\hline & Congestion & Degeneration & Necrosis & $($ Mean \pm SD $)$ \\
\hline Control & - & - & - & 0 \\
\hline GM & ++++ & ++++ & +++ & $3.33 \pm 0.516$ \\
\hline
\end{tabular}

$\begin{array}{lllll}\mathrm{GM}+\mathrm{EMP} & ++ & + & + & 1.50 \pm 0.547^{*}\end{array}$ $\mathrm{EMP}+(\mathrm{GM}+\mathrm{EMP})+\quad+\quad+1.16 \pm 0.408^{*}$

*p<0.05 compared to gentamicin treated group. Control- normal saline solutions only, GM- Gentamicin only, $G M+E M P$ - recieved Gentamicin and $M$. pendans extract, $E M P+(G M+E M P)$ - recieved $M$. pendans extract for 7 days and continued with Gentamicin and M. pendans extract.

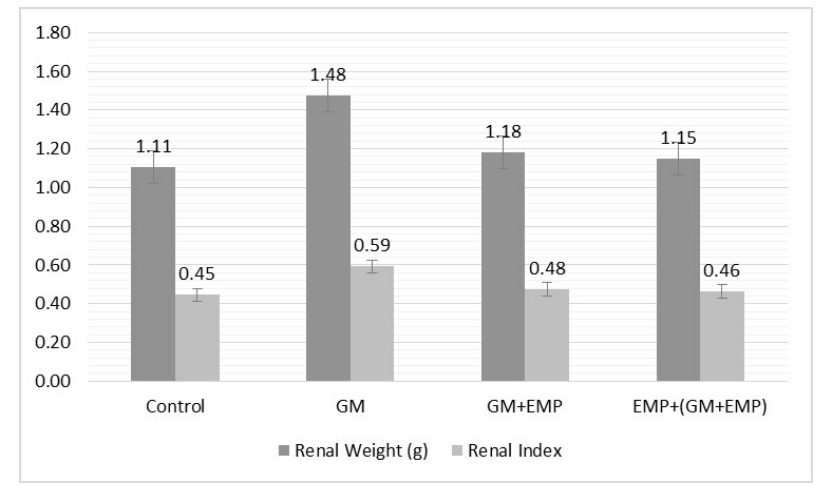

Fig. 1: Renal weight and index of experimental animals $\left({ }^{*} \mathrm{p}<0.05\right.$ compared with gentamicin treated group). Control-normal saline solutions only, GM- Gentamicin only, $G M+E M P$ - recieved Gentamicin and $M$. pendans extract, $E M P+(G M+E M P)$ - recieved $M$. pendans extract for 7 days and continued with Gentamicin and M. pendans extract.

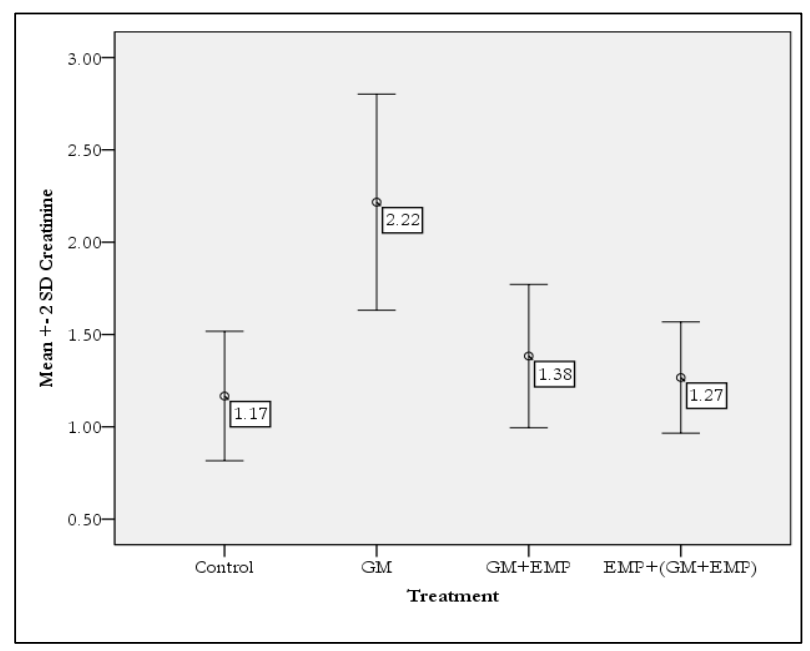

Fig. 2: Effect of M. pendas on serum creatinine levels $(\mathrm{mg} / \mathrm{dl})$ of nephrotoxic-rats (*significant at $\mathrm{P}<0.05$ compared with gentamicin treated group).

\section{DISCUSSION}

There was a significant $(\mathrm{P}<0.05)$ increase in the mean weight and renal index of rats which received gentamicin compared with the control group, indicated by a change in the shape of kidney cells or nephrons. The toxicity effect of gentamicin injection causes enlargement of rat kidneys (Saleemi et al. 2009). The kidneys act mainly in blood filtration and elimination of waste products derived from endogenous metabolism and xenobiotics (Modaresi and Po 2011). Its other functions include regulating homeostasis 


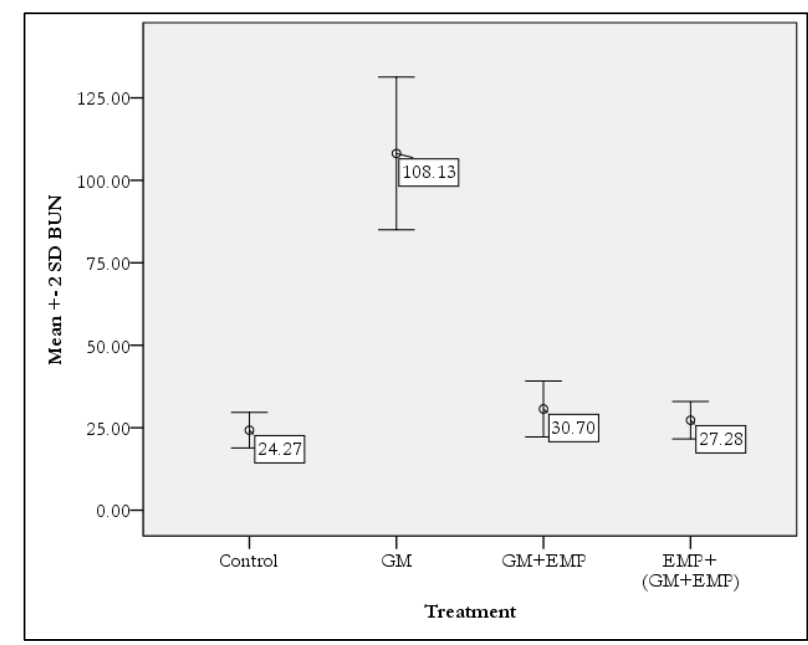

Fig. 3: Effect of $M$. pendas on BUN levels (mg/dl) of nephrotoxic-rats (*significant at $\mathrm{P}<0.05$ compared to gentamicin treated group).

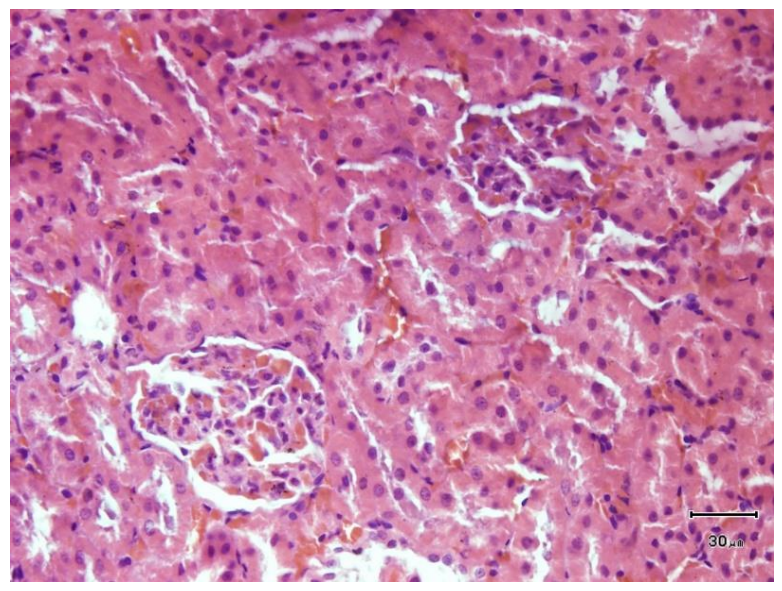

Fig. 4: Microphotograph of the renal of rat from the control group, showing normal glomerular and tubular histology (H\&E, x400).

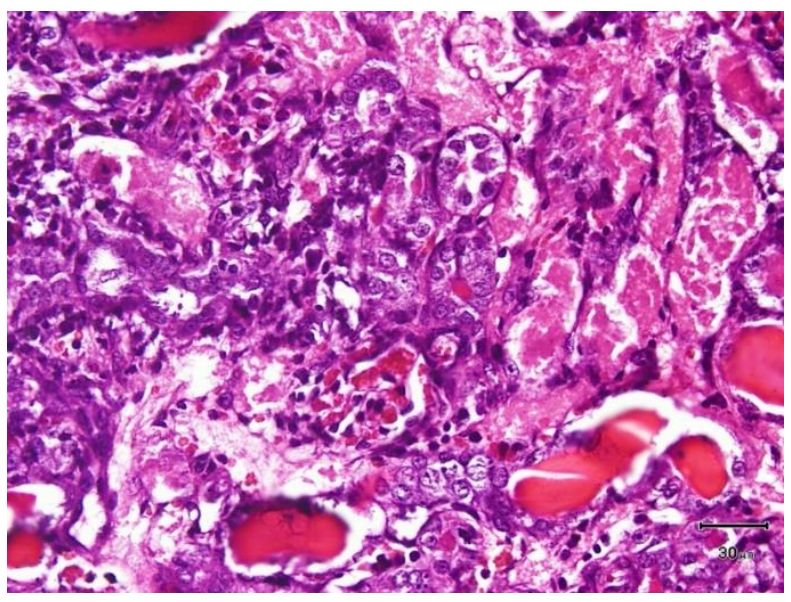

Fig. 5: Microphotograph of the renal of rat from gentamicin treated group showing severe hydropic degeneration, epithelial desquamation, tubular necrosis, interstitial edema, and vascular congestion (H\&E, $\mathrm{x} 400)$.

and secretion of substances such as renin, cholecalciferol, erythropoietin and prostaglandin. However, its continuous exposure to chemical compounds and other reactive metabolites makes it prone to drug-induced injuries.

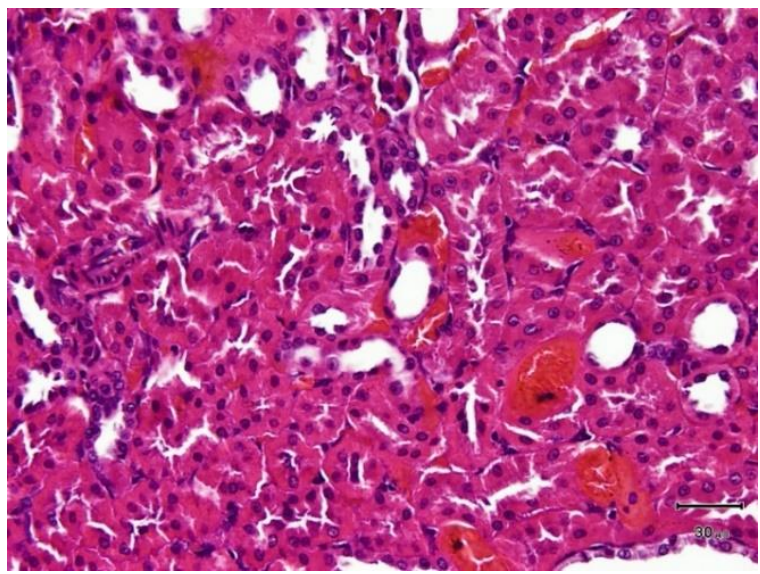

Fig. 6: Microphotograph of the renal of rat from group received gentamicin and $M$. pendans extract showing a moderate vascular congestion, and mild lesions of hydropic degeneration, epithelial desquamation and tubular necrosis (H\&E, x400).

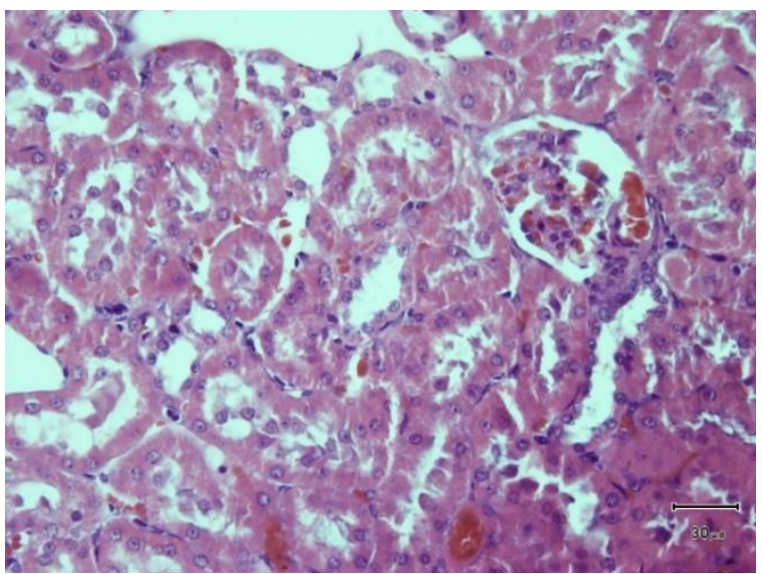

Fig. 7: Microphotograph of the renal of rat from group received ethanolic $M$. pendans extract for seven days and continued with gentamicin for the remaining days, showing mild lessions of vascular congestion, epithelial desquamation, degeneration, and tubular necrosis (H\&E, x400).

Changes in kidney cells or nephrons accompanied by the decreased function are known as kidney toxicity or nephrotoxicity (Nirogi et al. 2014; Marxfeld et al. 2019).

Based on this study, gentamicin successfully induced nephrotoxicity in the rats. The group which received 100 $\mathrm{mg} / \mathrm{kg} /$ day gentamicin for ten days experienced nephrotoxicity, which resulted in considerable increases in the levels of serum creatinine and BUN at 2.22 \pm 0.29 and $108.13 \pm 11.58 \mathrm{mg} / \mathrm{dl}$, respectively, compared with less than $1.2 \mathrm{mg} / \mathrm{dl}$ of serum creatinine and $8-25 \mathrm{mg} / \mathrm{dl}$ of BUN in the control group. Then, the histopathological examination showed some typical kidney lesions, which include tubular necrosis, epithelial desquamation, tubular congestion with nephrosis, lipidosis, hydropic degeneration, interstitial edema, and vascular congestion.

Gentamicin is a broad-spectrum antibiotic from the aminoglycoside group, widely used in humans and animals (Randjelovic et al. 2017). It is used due to its efficacy in treating infections and its relatively low price, without considering its nephrotoxic ability (Perazella 2018). The nephrotoxicity occurred due to the accumulation and resistance of aminoglycosides in proximal tubular epithelial cells. Previous research showed that the gentamicin-induced nephrotoxicity involves several mechanisms classified as 
vascular, glomerular and tubular (Quiros et al. 2011; Randjelovic et al. 2017; Mehmood et al. 2020).

Oxidative stress also plays a significant role in gentamicin-induced nephrotoxicity. It also in line with experiments that showed the healing of renal damage due to gentamicin-induced nephrotoxicity through the administration of antioxidants (Barnett and Cummings, 2018). Normally, oxidation has to do with the formation of reactive compounds, mediated by hydroxyl radicals and superoxide anions from hydrogen peroxide. Reactive oxidative species (ROS) are formed when aminoglycosides are released from epithelial cell lysosome (Ali et al. 2011). The release of these aminoglycosides causes swelling of the kidney cells, thereby inhibiting mitochondrial respiration and gentamicin increases the production of ROS in mitochondria (Jaeschke et al. 2012). These oxidative compounds inhibit the respiratory chain and ATP production, stimulate the release of cytochrome $\mathrm{C}$ and other proapoptotic factors, lipidosis, damaged cellular proteins and nucleic acids, induced mesangial contractions and cause endoplasmic reticulum stress (Ozbek 2012).

Transmembrane barriers result in an increase in cytosolic $\mathrm{Ca}^{2+}$, oxidative stress of the endoplasmic reticulum, and fat peroxidation, but decrease in the pumping of $\mathrm{Na}$ to an increase in the influx of $\mathrm{Ca}^{2+}$, water, and $\mathrm{Na}^{+}$into cells (Nolin and Himmelfarb, 2010). Mild injuries to the kidney, such as the edema of tubular epithelial cells accompanied by loss of brush border and desquamation of cells, are usually reversible (Ozbek 2012; Randjelovic et al. 2017). These lesions generally reduce kidney function and have the capacity to cause chronic kidney disease or cell death when left for a long time (Jaeschke et al. 2012; Perazella 2018; Amer et al. 2020).

The results of this study showed that $M$. pendans ethanol extract protected the kidneys from nephrotoxicity. Repaired parameters were observed from serum creatinine, BUN, renal index and histopathology scores, which were not significantly different from the control group. Induction of both $M$. pendans extracts and gentamicin significantly decreased the levels of serum creatinine and BUN, as well as the histopathological scores compared with the control group. The rats in group IV, in which $M$. pendans extract was administered for seven days before gentamicin induction, showed better results in terms of protection against the gentamicin-induced nephrotoxicity. The ability of $M$. pendans to overcome this condition was due to its antioxidant properties within free radicals scavenging activity (Engida et al. 2015; Sudiono et al. 2015). It is believed that the flavonoids and phenol in $M$. pendans are antioxidants compounds that directly bind and neutralize ROS due to the induction of gentamicin. These compounds are very effective against free radicals, thereby protecting the kidneys from gentamicin-induced nephrotoxicity (Khalid et al. 2011; Javaid et al. 2012; Jaeschke et al. 2012). Another study also showed the hepatoprotective ability of $M$. pendans, protecting rat liver from free radicals due to the induction of toxic doses of paracetamol (Merdana et al. 2019).

Based on the results, the ethanol extract of $M$. pendans at a dose of $250 \mathrm{mg} / \mathrm{kg} /$ day showed a nephroprotective effect against gentamicin. In addition, the extract maintained the weight and renal index of animals treated with it. Furthermore, the $M$. pendans reduced significantly $(\mathrm{P}<0.05)$ the serum creatinine and BUN levels, as well as the histopathology score of rats administered with it compared with the nephrotoxic groups. These results were in line with other studies using different plant extracts, but with similar active compounds capable of preventing nephrotoxicity (Salem et al. 2010; Ajami et al. 2010; Elamir et al. 2019).

\section{Conclusion}

The administration of $250 \mathrm{mg} / \mathrm{kg}$ body weight $M$. pendans ethanolic extract protected the Wistar rats against gentamicin-induced nephrotoxicity. Therefore, this study concluded that the ethanolic extract of $M$. pendans has a nephroprotective activity. However, further study is needed to elucidate the specific compounds of $M$. pendans and understanding the mechanisms involved in its protection.

\section{Acknowledgment}

The authors are grateful to the Rector of Udayana University, the dean of the Faculty of Veterinary Medicine and the head of the Institute of Research and Community Service, Udayana University, for providing the research grant.

\section{Author's contribution}

All authors were actively involved from the start of the research planning, experimentation, analyzing of research data, drafting and the completion of the manuscripts. However, IMM and NLW designed and supervised the research. AGA, LMD and $\mathrm{KB}$ collected the samples. In addition, IWS and NFG conducted the laboratory tests and data analysis, while IMM and IWS drafted and completed the manuscripts.

\section{REFERENCES}

Acharya C, Thakar H and Vajpeyee SA, 2013. Study of oxidative stress in gentamicin induced nephrotoxicity and effect of antioxidant vitamin $\mathrm{C}$ in Wistar Rats. National Journal of Physiology Pharmcy Pharmacology 3: 14-20. https://doi.org/ 10.5455/njppp.2013.3.14-20

Ajami M, Eghtesadi S, Pazoki-Toroudi H, Habibey R and Ebrahimi SA, 2010. Effect of crocus sativus on gentamicin induced nephrotoxicity. Biological Research 43: 83-90. http://doi.org/10.4067/S0716-97602010000100010

Alarifi S, Al-Doaiss A, Alkahtani S, Al-Farraj SA, Al-Eissa MS, Al-Damash B, Al-Yahya H and Mubarak M, 2012. Blood chemical changes and renal histological alterations induced by gentamicin in rats. Saudi Journal of Biological Sciences 19: 103-110. https://doi.org/10.1016/j.sjbs.2011.11.002

Ali BH, Za'abi MA, Blunden $\mathrm{G}$ and Nemmar A, 2011. Experimental gentamicin nephrotoxicity and agents that modify it: A mini-review of recent research. Basic and Clinical Pharmacology \& Toxicology 109: 225-232. https://doi.org/10.1111/j.1742-7843.2011.00728.x

Amer MM, Amer AM, Hassan ER and Ghetas AM, 2020. Salmonella Enteritidis in broiler chickens: isolation, antibiotic resistance phenotyping and efficacy of colistin on control of experimental infection. International Journal of Veterinary Science 9: 267-272.

Barnett LMA and Cummings BS, 2018. Nephrotoxicity and renal pathophysiology: a contemporary perspective. Toxicological Sciences 164: 379-390. https://doi.org/10.1093/toxsci/kfy159.

El-Amir YO, Omar W, Khabrani AY, Jahfali AE, Alhakami SM and Dobab NM, 2019. Protective effect of avenanthramides against cisplatin induced nephrotoxicity in rats. Journal of Advanced Veterinary and Animal Research 6: 521-527. https://doi.org/10.5455/javar.2019.f377

Engida AM, Faika S, Nguyen-Thi BT and Ju Y, 2015. Analysis of major antioxidants from extracts of Myrmecodia pendans by UV/visible spectrophotometer, Liquid Chromatography/ 
tandem Mass Spectrometry, and High-performance Liquid Chromatography/UV Techniques. Journal of Food and Drug Analysis 23: 303-309. https://doi.org/10.1016/j.jfda.2014. 07.005

Epsilawati L, Satari M and Azhari. 2019. Analysis of Myrmecodia Pendens in bone healing process to improve the quality of life: literature review. IOP Conference Series: Earth and Environmental Science 248: Article \# 012052. https://doi.org/10.1088/1755-1315/248/1/012052

Feldman AT and Wolfe D, 2014. Tissue Processing and Hematoxylin and Sosin Staining. In: Day C (ed), Histopathology: Methods in Molecular Biology (methods and protocols). Humana Press, New York, NY. pp: 31-43.

Gartika M, Pramesti HT, Kurnia D and Satari MH, 2018. A terpenoid isolated from sarang semut (Myrmecodia pendans) Bulb and its potential for the inhibition and eradication of Streptococcus mutans biofilm. BMC Complementary and Alternative Medicine 18: 151. https://doi.org/10.1186/ s12906-018-2213-x

Geller SA and Horowitz RE, 2014. Gross examination. In: Day C (editor), Histopathology: methods in molecular biology (methods and protocols). Humana Press, New York, pp: 3-19.

Hertiani T, Sasmito E, Sumardi and Ulfah M, 2010. Preliminary study on immunomodulatory effect of sarang-semut tubers Myrmecodia tuberosa and Myrmecodia pendens. OnLine Journal of Biological Sciences 10: 136-141. https://doi.org/10.3844/ojbsci.2010.136.141

Islamoyo M, Aldi Y and Nelis S, 2017. Uji anti inflamasi secara topikal ekstrak etanol umbi sarang semut (Myrmecodia tuberosa Jack) pada mencit putih jantan. Andalas Dental Journal 52: 112-121. https://doi.org/10.25077/adj.v5i2.77

Jaeschke H, McGill MR and Ramachandran A, 2012. Oxidant stress, mitochondria and cell death mechanisms in druginduced liver injury: lessons learned from acetaminophen hepatotoxicity. Drug Metabolism Reviews 44: 88-106. https://doi.org/10.3109/03602532.2011.602688

Javaid R, Aslam M and Nizami Q, 2012. Role of antioxidant herbal drugs in renal disorders: An overview. Free Radicals and Antioxidants 2: 2-5. https://doi.org/10.5530/ax.2012.2.2

Javed U, Khan MZ, Saleemi MK, Khan A, Javed I and Rafique S, 2013. Toxico-pathological effects of parenteral administration of gentamicin in growing broilers. International Journal of Agriculture and Biology 15: 529-534.

Kapić D, Mornjaković Z, Cosović E and Šahinović M, 2014. A histological study of the effect of exogenous melatonin on gentamicin induced structural alterations of proximal tubules in rats. Bosnian Journal of Basic Medical Sciences 14: 3034. https://doi.org/10.17305/bjbms.2014.2293

Khalid M, Siddiqui HH and Freed S, 2011. Free radical scavenging and total phenolic content of Saccharum spontaneum L. root extracts. International Journal of Research Pharmacy and Chemistry 1: 1160-1166.

Lee CT, Chen HC, Ng HY, Lai LW and Lien YHH, 2012. Renal adaptation to gentamicin-induced mineral loss. American Journal of Nephrology 35: 279-286. https://doi.org/10.1159/ 000336518

Marxfeld HA, Küttler K, Dammann M, Groters S and Ravenzwaay BV, 2019. Body and organ weight data in 28-day toxicological studies in two mouse strains. Data in Brief 27: Article \# 104632. https://doi.org/10.1016/j.dib.2019. 104632

Mehmood K, Bilal RM and Zhang H, 2020. Study on the genotypic and phenotypic resistance of tetracycline antibiotic in Escherichia coli strains isolated from free ranging chickens of Anhui Province, China. Agrobiological Records 2: 63-68. https://doi.org/10.47278/ journal.abr/2020.014

Merdana IM, Watiniasih NL, Sudira IW and Samsuri, 2019. The Effect of Ethanol Extract Mymercodia pendans on Paracetamol-Induced Hepatotoxicity in White Rats. IOP Conference Series Earth and Environmental Science 248: Article \# 012045. https://doi.org/10.1088/1755-1315/248/1 $/ 012045$
Modaresi M and Pour MG, 2011. Effect of Zingiber extract on histopathologic changes in mice kidneys. Research Journal of Applied Sciences 6: 295-298. http://doi.org/10.3923/ rjasci.2011.295.298

Nirogi L, Goyal VK, Jana S, Pandey SK and Gothi A, 2014. What suits best for organ weight analysis: review of relationship between organ weight and body / brain weight for rodent toxicity studies. International Journal of Pharmaceutical Sciences and Research 5: 1525-1532. http://dx.doi.org/ 10.13040/IJPSR.0975-8232

Nolin TD and Himmelfarb J. 2010. Mechanisms of drug-induced nephrotoxicity. In: Uetrecht J. (eds) Adverse Drug Reactions. Handbook of Experimental Pharmacology 196: 111-130. https://doi.org/10.1007/978-3-642-00663-0_5

Ozbek E, 2012. Induction of oxidative stress in kidney. International Journal of Nephrology 2012: Article \# 465897 https://doi.org/10.1155/2012/465897

Perazella MA, 2018. Pharmacology behind common drug nephrotoxicities. Clinical Journal of American Society Nephrology 13: 1897-1908. https://doi.org/10.2215/CJN 00150118

Quiros Y, Vicente-Vicente L, Morales AI, Lopez-Novoa JM and Lopez-Hernandez FJ, 2011. An integrative overview on the mechanisms underlying the renal tubular cytotoxicity of gentamicin. Toxicological Sciences 119: 245-256. https://doi.org/10.1093/toxsci/kfq267

Randjelovic P, Veljkovic S, Stojiljkovic N, Sokolovic D and Ilic I, 2017. Gentamicin Nephrotoxicity in Animals: Current Knowledge and Future Perspectives. EXCLI Journal 16: 388-399. https://doi.org/10.17179/excli2017-165

Saleemi MK, Zargham Khan M, Javed I, Khan A, 2009. Pathological effects of gentamicin administered intramuscularly to day-old broiler chicks. Experimental and Toxicologic Pathology 61:425-432. https://doi.org/10.1016/ j.etp.2008.10.006

Salem EA, Salem NA, Kamel M, Maarouf AM, Bissada NK, Hellstrom WJG and Eladl M, 2010. Amelioration of gentamicin nephrotoxicity by green tea extract in uninephrectomized rats as a model of progressive renal failure. Renal Failure 32: 1210-1215. https://doi.org/ $10.3109 / 0886022 X .2010 .517350$

Salgueiro SR and Núñez LG, 2015. Morphological methods to evaluate protective agents against aminoglycoside-induced nephrotoxicity. Journal of Renal Injury Prevention 4: 1-3. https://doi.org/10.12861/jrip.2015.01

Soeksmanto A, Subroto MA and Wijaya H and Simanjuntak P, 2010. Anticancer activity test for extracts of Sarang semut plant (Myrmecodya pendens) to HeLa and MCM-B2 cells. Pakistan Journal of Biological Sciences 13: 148-151. https://doi.org/10.3923/pjbs.2010.148.151

Sudiono J, Oka C and Trisfilha P, 2015. The scientific base of Myrmecodia pendans as Herbal remedies. Journal of Advances in Medicine and Medical Research 8: 230-237. https://doi.org/10.9734/BJMMR/2015/17465

Wimpy S, 2014. Antioxidants activity of Myrmecodia pendans extract combine with Annona muricata leaf extract using DPPH (2,2-Diphenyl-1-Picrilhidrazyl). Journal of Pharmacy 4: 18-24. https://doi.org/10.37013/jf.v3i1.22

Yap LS, Lee WL and Ting ASY, 2017. Endophytes from Malaysian medicinal plants as sources for discovering anticancer agents. In: Agrawal DC, Tsay HS, Shyur LF, Wu YC, Wang SY (editors), Medicinal Plants and Fungi: recent advances in research and development. Medicinal and Aromatic Plants of the World 4. Springer, Singapore. https://doi.org/10.1007/978-981-10-5978-0_10

Zhang QW, Lin LG and Ye WC, 2018. Techniques for extraction and isolation of natural products: A comprehensive review. Chinese Medicine 13: 1-26. https://doi.org/10.1186/s13020018-0177-x 